\title{
A lição da pedra: usos do passado e cultura material
}

\author{
The lesson of the stone: uses of the past and material culture
}

\author{
Francisco Régis Lopes Ramos \\ regisufc@hotmail.com \\ Professor \\ Universidade Federal do Ceará \\ Rua General Silva Júnior, 800/802 - Fátima \\ 60411-200 - Fortaleza - CE \\ Brasil \\ Aline Montenegro Magalhães \\ alinemontenegro@gmail.com \\ Historiadora \\ Museu Histórico Nacional \\ Praça Marechal Âncora, s/n - Centro \\ 20021-200 - Rio de Janeiro - RJ \\ Brasil
}

\section{Resumo}

Ao propor certas divisões entre o passado e o presente, a escrita da história na modernidade também articula várias maneiras de fazer conexões entre o real e o que não é real. Uma possível abordagem historiográfica é exatamente o estudo sobre a forma como essas conexões são constituídas e legitimadas. Portanto, este artigo é uma abordagem historiográfica sobre os usos do passado na cultura histórica vivida por Gustavo Barroso, a partir das proposições teóricas e metodológicas de Manoel Luiz Salgado Guimarães. Relacionando a escrita de Barroso com a produção de outros intelectuais, percebe-se o importante papel da cultura material para a construção de certas formas de dar sentido ao passado, através das transformações de marcas e traços em vestígios da passagem do tempo.

\section{Palavras-chave}

Escrita da História; Narrativas; Cultura material.

\begin{abstract}
By proposing certain divisions between past and present, modern history writing also articulates various connections between what is real and what is not real. A viable historiographical approach is exactly the study of the way these connections are structured and legitimized. Therefore, this article investigates the uses of the past in historical culture as experienced by Gustavo Barroso. Based on theoretical and methodological insights by Manoel Luiz Salgado Guimarães, it relates Barroso's writing to the production of other intellectuals. The paper aims at illustrating the significant role material culture has in the shaping of certain ways of giving meaning to the past, more specifically through the transformation of marks and traces into vestiges of the passage of time.
\end{abstract}

\section{Keywords}

History writing; Narratives; Material culture.

Recebido em: 16/7/2013

Aprovado em: 8/9/2013 
O que parece construir esta possibilidade da representação, no caso da História, é a absoluta consciência de uma perda, de uma ausência insubstituível e incontornável, aquela do próprio passado como experiência, que despertara nas sociedades do século XIX uma paixão pela História em suas mais diversas formas (GUIMARÃES 2010, p. 48).

\section{A pátina do tempo}

José de Alencar escreveu que, diante das ruínas de Olinda, "interrogava os muros do convento, como para arrancar-lhes o segredo de algum fato interessante de que se perdera a tradição". A vida, afinal, não passava para sempre, deixava marcas e marcos: "Era justamente essa crônica do coração, esquecida pelos analistas do tempo, que eu pedia àquelas ruínas" (ALENCAR 1953, p. 238).

A pedra era tanto a presença de uma ausência, quanto a ausência de uma presença. Ao contrário do que pode parecer, não é simplesmente um jogo de palavras. Para ser sentida, a ausência deve dar conta de alguma existência anterior. A reverência diante do antigo vem desse sentimento: ali há muitas ausências, sobrepostas e repostas. Sem imaginar que por ali muitas coisas se passaram, perde-se o elo fundante da saudade. Não propriamente uma saudade de ausentes conhecidos, mas a falta de algo que não se sabe bem o quê. Uma indefinição propícia à imaginação. Daí a necessidade dessa presença radical de um existente que não existe mais. Daí a necessidade de ver o aparentemente invisível.

Alencar pedia, perguntava, implorava, mas a matéria permanecia calada: "os muros, lavados pela chuva e pelo vento, estavam descarnados; as pedras já não conservavam os vestígios da mão do homem". Os vestígios estavam mudos e mutilados: "Quantas vezes não sondei esses destroços de alvenaria, essas paredes nuas, procurando, nem sei o quê, uma memória, um nome, uma inscrição, uma frase que me revelasse algum mistério, que me dissesse o epílogo de alguma lenda que a imaginação completaria!" (ALENCAR 1953, p. 238).

Pedra boa era pedra riscada, ou melhor, acrescida por algum tipo de grafia. Alencar procurava aquilo que Victor Hugo havia encontrado em uma parede de uma catedral do medievo: uma inscrição. 'AN' ATKH - foi essa a palavra que fez Victor Hugo meditar, como ele mesmo escreveria depois: "Estas maiúsculas gregas, enegrecidas pelo tempo e profundamente gravadas na pedra [...] impressionaram vivamente o autor". Daí, o romancista encontrou a sua matéria-prima, no mesmo dispositivo de criação que Alencar tentava pôr em prática: a faculdade de imaginar a partir de indícios enigmáticos. Ali, diante das letras, ele perguntou a si mesmo "qual teria sido a alma aflita, que não tinha querido abandonar este mundo sem deixar aquele estigma do crime ou da desgraça na fronte da velha igreja" (HUGO 2011, p. 6).

Diferentemente dos muros "lavados" onde Alencar buscava seu romance, a Notre Dame tinha aquele pormenor significativo, que se via, por exemplo, nas grafias em baixo relevo. Aqueles pequenos resíduos, lentamente entranhados no sulco da letra, davam à pedra aquilo que somente o tempo poderia dar: a impureza das camadas, a mistura das poeiras pacientes. Nada como esses sedimentos que irritam o nariz: insistentes, as partículas vão fazendo a tintura 
da impressão, regadas pela umidade das estações que se repetem a cada ano. Para um romântico, isto não é menor. Daí é que a letra ganha força para transcender a sua imobilidade ancestral. Do cisco no olho, em ventanias de séculos e séculos, pode vir a escrita que os românticos idealizam.

Sempre será possível imitar uma pedra antiga, mas nunca a idade da pedra. Era nesse aforismo que o tempo ganhava espessura. Victor Hugo observou isso no mínimo detalhe. Ele chegou a fazer um esquema explicativo para dar conta das avarias que Notre Dame vinha passando desde a sua origem. Eram três as causas: o tempo, as revoluções e a moda. Para ele, a pior e a mais danosa era a última. A primeira, como era de se esperar, se mostrou ambígua. O tempo, afinal, também construía: "[...] talvez o tempo tenha acrescentado mais à igreja do que subtraído, pois expandiu sobre essa fachada a sóbria cor dos séculos, que faz da velhice dos monumentos a idade de sua beleza" (HUGO 2011, p. 147).

A palavra 'AN' ATKH, vale destacar, não foi o único motor do livro que seria gerado. Sua literatura, além de tudo, seria uma denúncia: "Depois a parede foi rebocada ou raspada (não sei qual das coisas foi), e a inscrição desapareceu. É assim que se pratica há quase duzentos anos com as maravilhosas igrejas da idade média. As mutilações vem [sic] de todos os lados" (HUGO 2011, p. 6).

Não é inadequado, portanto, avaliar o papel da ficção em um estudo sobre a história do patrimônio, como fez Dominique Poulot, pondo em relevo os escritos de Victor Hugo e Balzac na composição de novos sentidos para a valorização da ideia de preservação na França. Poulot considera a ficção algo central no cultivo de sentimentos afeitos à conservação e à composição de conexões entre o "antigo" e o "belo". Daí a sua preocupação em incluir no decorrer dos argumentos algumas ponderações sobre a "eficácia da literatura na patrimonialização" (POULOT 2009, p. 161). Nessa linha de raciocínio, não seria um despropósito inserir José de Alencar numa história do patrimônio ou da historiografia.

Alencar tem sua matéria-prima no tempo, apropriada e recomposta em proposições que, em cada romance, seguem vias mais ou menos específicas, mas sempre atreladas a uma preocupação com a legitimidade do passado. Enquanto a sua História do Ceará começa nos "verdes mares", com Martim e seu filho se despedindo de Iracema, a sua história do Rio de Janeiro começaria em um ponto mais delimitado, tanto no tempo quanto no espaço. O relato iniciaria no "momento em que se lançou a primeira pedra da construção da cidade". O projeto previa o uso da imaginação historicamente fundamentada e, por isso, o seu Rio de Janeiro no decorrer do tempo seria mais real: "Talvez me censurem por isto e julguem que desci da verdade à poesia; tenho porém a consciência de que a imaginação aí não faz mais do que dar um corpo aos objetos que o espírito vê com os olhos d'alma, e ligar os diversos fragmentos que se encontram nos livros". "Demais sou historiador à minha maneira", conclui Alencar (1981, p. 111). Alencar historiador? Ao seu modo, sim (PELOGGIO 2004, p. 83). Mas o que significa "ao seu modo"? Em princípio, completar o que faltava com a imaginação. Sem imaginação, nada poderia ser escrito. Mas, sem pesquisa, tudo seria falso. A verdade da ficção, no final das contas, vinha da imagem pesquisada no tempo. 
Alencar não fazia hierarquia entre as fontes. Tanto a tradição oral quanto a escrita tinha o mesmo peso. A arqueologia, a botânica, a história, nada disso poderia ser descartado. Tudo em nome do romance, que, para Alencar, seria a única escrita capaz de juntar os fragmentos e compor a verdadeira imagem do passado, exatamente porque a ficção sabia como e por que imaginar, com critérios confiáveis e comoventes. Daí a importância da pedra no seu projeto para uma História do Rio de Janeiro: ora fonte que sustenta a existência do fato, ora desafio que induz a criação da fábula. "Vou folheando", explica Alencar, "uma a uma as páginas desse álbum de pedra [...]; no qual o tempo, esse sublime arquiteto de ruínas, elevou umas sobre as outras estas diversas gerações de casas, sob cujos tetos desapareceram outras tantas gerações de homens". Conclusão: "[...] não estranhe se algumas vezes me arrogo o título pomposo de historiador; uso desta palavra, como quem diria, simples e fiel narrador daquilo que leu e ouviu" (ALENCAR 1981, p. 112). Já que a escrita da história não se dava em um campo bem definido, Alencar aproveitou as brechas para dizer que seu ofício de escritor englobava, de alguma maneira, o trabalho de um historiador.

\section{O passado em ruínas e outros vestígios}

Século XIX: "esse é o século da história no sentido da profissionalização da prática histórica que se dota, por toda parte na Europa, de um programa para seu ensino, de regras metodológicas, e que rompe com a literatura para voar com asas próprias". A avaliação é de François Dosse (2010, p. 15). Mas, a rigor, trata-se de uma espécie de senso comum que foi se estabelecendo no âmbito da historiografia ou da história da historiografia. Obviamente uma conclusão tão geral não poderia ser um consenso. Entre as ponderações que podem rever a solidez desse edifício interpretativo, dou destaque a duas. Primeira: a memória disciplinar da história científica, que vai desqualificar tanto o século XVIII iluminista quanto as tradições da sensibilidade antiquária, em nome de uma superioridade do próprio fechamento disciplinar. Segunda: a formação do campo disciplinar da história não se conclui no século XIX, nem pode ser tomada como um fenômeno que segue certos passos predeterminados. No Brasil do século XX, a escrita da história não se divorcia completamente da ficção, não dá fim aos procedimentos do romantismo, nem elimina a sensibilidade antiquária. Em outros termos: a voz da pedra continua a ter vez em zonas de contato entre história e literatura. Se no século anterior Alencar foi destaque, no seguinte uma das referências será Gustavo Barroso.

"Além da história", escreve Barroso, "as pedras testemunham a arte". Isso quer dizer que acumulam sentimentos de épocas extintas e, portanto, também afetam a pele do estudioso: "Não somente nossos olhos se agradam em ver o lavrado nas pedras antigas; nossas mãos se prazem em acariciar uma moldura, uma arrecada, um rendilhado que o cinzel carinhosamente abriu na matéria bruta ao sopro duma inspiração superior". O trecho é de um relato de viagem a Portugal e se refere, mais especificamente, às suas visitas aos castelos medievais em 1940. Sua ida à "pátria lusitana" deveu-se à função de representante do Brasil, encarregado de montar um dos setores da "Exposição 
dos Centenários", com o acervo que ele mesmo selecionou no Museu Histórico Nacional, onde ele ocupava o cargo de diretor e, além disso, o honroso título de fundador da instituição. Daí surgiu o livro Portugal, semente de impérios. Embora tendo o integralismo como fase já finda em sua vida, o próprio título do relato já indica que sua admiração por Salazar não era pequena. Conhecê-lo foi comovente, sem dúvida. Mas nada se comparou ao encerramento dos desfiles e dos espetáculos ao redor do velho castelo de Guimarães, lugar em que se reafirmava na narrativa patriótica como o começo de Portugal:

E de todos os pontos do castelo, e de todos os ângulos da vasta praça fronteira desabrocaram fogos de artifício, enchendo o céu noturno de flores e de estrelas de ouro, de prata, de rubi, de ametista e de esmeralda. Quando tudo se apagou na noite negra e profunda, somente o velho castelo ficou iluminado como um Sonho de Pedra.

Passando rente a mim, Antônio Ferro bateu-me no ombro e perguntou: - Que tal?

Maurício Maeterlinck, que o acompanhava, repetiu a pergunta, acrescentando:

- "Je suis ravi"!

- Foram precisos oito séculos para se preparar isto! (BARROSO 1943, p. 20).

O espaço até pode ser copiado; o tempo, não. É nessa constatação que as ruínas assumem um papel completamente insubstituível. Em outros termos: é possível fazer com perfeição a cópia de uma casa de 300 anos, mas a cópia será apenas do espaço. Jamais se terá a imitação dos 300 anos. O antigo só pode ser atributo de um objeto se o tempo passa. Nunca será possível construir um artefato de 300 anos em três dias. O romantismo lida com essa massa temporal, adquirida em ritmo próprio, por tudo aquilo que envelhece.

Isso, na teoria. Na prática, a história é outra, porque foi nos primórdios do romantismo que se espalhou o gosto pela reprodução de objetos históricos, incluindo as próprias ruínas. A partir do século XVIII, não faltou criatividade para quem quisesse ter a sua própria ruína, no lugar que desejasse. Alguns arquitetos orientavam, por exemplo, que a melhor maneira era fazer construções "medievais" com material de maior fragilidade, assim logo começariam a cair. Outros já colocavam pedaços de muro cuidadosamente espalhados em um jardim, à espera de lodo ou coisa parecida. Havia, também, os mais cuidadosos: arrancavam pedaços de construções antigas e depositava-os no terreno a ser decorado com o pretérito. Por fim, os radicais: erguiam castelos e, logo em seguida, bombardeava-os. Da explosão é que surgiriam as ruínas projetadas. Como era de se esperar, o artifício foi logo denunciado como artificialidade de mau gosto. Na França, levantou-se a voz de Delille: "Aproveitem esses restos venerados de capelas, fortalezas ou abadias respeitáveis ou comoventes, profanos ou sagrados; mas mantenham-se afastados desses monumentos cuja fingida ruína imita mal a inimitável marca do tempo..." (CARENA 1984, p. 199-120).

Em 1931, quando visitou Paris, Barroso fez algumas anotações sobre seu deslumbre diante da fachada monumental de Notre Dame, misturando descrições de detalhes da arquitetura, vistos no calor da hora, com divagações a respeito 
de datas e fatos relativos ao lugar. E, como era do seu feitio, ele polemizou, exatamente para mostrar o caráter específico de uma pedra memorável:

Lembro-me, então, terem os jornais parisienses anunciado que um milionário ianque, apaixonado pela beleza da catedral de Notre Dame, sabendo estarem essas torres inconclusas desde o século XIII, procurara o Arcebispo de Paris e Ihe entregara um cheque em branco para que terminasse aquela obra. Não sei o que Ihe respondeu o Arcebispo, mas sei que, se fosse ele, teria dito ao generoso norte-americano o seguinte: - Permita que use este cheque em benefício de hospitais e orfanatos. Quanto às torres da catedral, devem ficar e ficarão como se acham. Nem todo o ouro do mundo será bastante para concluí-las. Isto só seria possível com os artistas e artesãos do século XIII, com a mentalidade daquela época. Não se compra o passado como se compram melões ou consciências... Se meu alvitre não Ihe apraz, leve de volta seu cheque. A igreja de Notre Dame é um patrimônio sagrado, não somente da França, mas da humanidade. Pedreiros modernos com instrumentos modernos, se Ihe tocarem, a conspurcarão. Toda a sua grandeza está na sua idade, no que ela nos diz como expressão dum tempo que se foi e nunca mais voltará (BARROSO 1946, p. 180).

Até onde? Até quando? Como parar uma construção que passou boa parte da sua vida em reformas, reconstruções e reparos? Nem Victor Hugo nem Barroso ignoravam a impureza do monumento. Sabiam que era impossível marcar com precisão uma data de conclusão do templo, para daí estabelecer a essência da estrutura. Não se deve, entretanto, procurar uma coerência nesse sentido, porque não há nem poderia haver esse ordenamento esquemático do tempo. O modo pelo qual os dois autores lidavam com o tempo pressupunha tais camadas de acréscimos e perdas, ora lamentadas, ora louvadas, a depender da circunstância. O vigor com que eles defendiam a preservação diante das "modas" era radical, mas a degradação inevitável da matéria era conhecida e reconhecida. Para o futuro distante, somente a literatura poderia salvar esses monumentos. Primeiro, porque saberia evidenciar a "alma" que os sustentavam. Segundo, porque o livro poderia ser reimpresso, e assim resistiria à passagem dos séculos. Daí a ânsia pelo registro escrito, tanto em relatos de viagem, quanto em romances. Daí, por exemplo, as quase intermináveis descrições de Victor Hugo no meio da narrativa, revelando não somente o tempo no qual ocorre a trama, mas sempre se reportando aos séculos anteriores, para mostrar algum detalhe da "antiga Paris", que o tempo havia levado.

Compunha a prática da escrita romântica a junção entre o lamento e a revolta, entre contemplação e intervenção. Não é de se estranhar, portanto, as divagações filosóficas de Barroso sobre o espírito sensível ao tempo incrustrado na pedra. Nos seus escritos, vale destacar, o romantismo não era apenas assumido, mas também se tornava matéria de reflexão e de combate aos que não sabiam sentir. No meio das pedras veneráveis de Guimarães, em busca das imagens que apareciam pela infusão do ambiente, ele pensou: "A semente do romantismo é a mais difícil de extirpar do coração humano. Dentro do nosso coração canta sempre uma balada. [...] E desgraçados de nós se assim não fosse, se só tivéssemos o senso objetivo da triste e dura realidade" (BARROSO 1943, p. 104). 
Não é o caso, obviamente, de concordar com Barroso sobre o sentido quase atemporal dos sentimentos românticos. O que interessa é pensar sobre a relação entre disciplinarização da escrita da história e o funcionamento dessa sensibilidade que ora vem como saudade, ora como melancolia. Ora como porta de entrada para o passado, ora como vontade de vasculhar a terra para ver, pelo menos em parte, as raízes do presente.

Em certa medida, esse apego à pedra polida pelo tempo não é invenção dos românticos. O desgaste da matéria também fazia parte dos valores de um tipo de uso do passado que hoje pode ser chamado de sensibilidade antiquária - um uso do passado que foi posto em posição inferior pela concepção científica do século XIX, criando certos estereótipos que passaram a fazer parte da memória disciplinar da história.

Os estereótipos diante dos antiquários, que os colocam na qualidade de conhecimento desarranjado e desconexo, movimentam-se no meio de uma "derrota da erudição" e em nome da filosofia da história, que vai dar um sentido de utilidade prática ao saber sobre o pretérito. Como bem ressalta Manoel Luiz Salgado, "estavam sendo postos em marcha dispositivos intelectuais que transformarão progressivamente este conjunto material em 'fontes' para a escrita da História" (GUIMARÃES 2008, p. 48).

\section{A pedra domesticada na Casa do Brasil}

No Museu Histórico Nacional, a "Casa do Brasil" para Gustavo Barroso, 102 também se recorreu à pedra como meio de acesso ao passado. Recolhida na terra, entre escombros de edificações destruídas ou em ruínas desenganadas, foi objeto e suporte para uma escrita da história não convencional, tridimensional, que articulou disciplinarização de um campo do saber e sensibilidade antiquária. Nesse casamento, escrevia-se a história pátria dos considerados grandes eventos políticos e militares, lançando mão da cultura antiquária, fundamental para a seleção e interpretação dos vestígios materiais que comprovariam a existência dos acontecimentos e para a valoração desses objetos como relíquias para o "culto da saudade" (BARROSO 1997). Nessa perspectiva, recorria-se a duas raízes da cultura clássica para fabricar o passado nacional no interior do antigo Arsenal de Guerra da Corte: uma história à moda Tucidideana e uma prática de pesquisa antiquária. (MOMIGLIANO 2004) Ambas também retomadas no século XIX formando as bases da História, disciplina que tenta tomar para si o domínio sobre o passado, sendo que, neste caso, o casamento não foi tão harmonioso como pareceu no museu. Assim mostra Guimarães:

Ao se distanciarem dessa tradição, apontando os seus limites, mas também formulando uma maneira própria de incorporá-la pela via das "ciências auxiliares da história", os historiadores da geração romântica pretendem para o exercício do ofício um novo estatuto, novas regras e procedimentos [...] (GUIMARÃES 2011, p. 104).

A existência de uma "Arcada das pedras", entre os espaços da exposição permanente do Museu Histórico Nacional de 1924, descrito no Catálogo geral 
da Primeira Seção - Arqueologia e História (MHN 1924, p. 36-40), é no mínimo instigante. Pois o nome não remete o visitante a nenhum fato consagrado pela historiografia oficial, nem a personagem algum tornado herói, mas sim a uma coleção muito específica que, no catálogo abrange "todas as épocas". Trata-se de um espaço dedicado aos restos. Entre os 43 itens, em sua maioria, fragmentos de construção, duas pedras que encimavam a entrada de parte do Antigo Arsenal de Guerra da Corte. Uma com a inscrição "1822" e a outra "1835". Foram recolhidas pelo Museu Histórico Nacional em 1922, quando o conjunto arquitetônico que desde então o abriga deixava para trás suas funções militares para as quais fora construído, e se vestia no estilo neocolonial para abrigar o Pavilhão das Grandes Indústrias da monumental Exposição Internacional Comemorativa do Centenário da Independência. Nessa reforma de embelezamento e de definição de novas funções para as edificações da Ponta do Calabouço, as duas pedras perdiam sentido na fachada do prédio do antigo Arsenal. Não diziam mais sobre o que havia no lugar, estavam deslocadas no tempo e no espaço. Por isso, retiradas, transformadas em fragmentos, parte de um todo a ser constituído pelo trabalho da imaginação, da memória ou da história.

A modernidade que se desejava para a cidade do Rio de Janeiro, suas ruas e edificações não sustentava determinadas pedras. Por isso elas rolaram do antigo Arsenal e também do Morro do Castelo, desmontado no mesmo ano de 1922, e foram parar na "Casa do Brasil". A nação centenária desejava o progresso e domesticava pedras como forma de reter uma espécie da autenticidade do que se perdia. E assim, azulejos e frontal que restaram do antigo Convento dos Jesuítas, bem como o friso do portão do velho forte que ficava lá no alto, com suas inscrições de 1713, podiam testemunhar a existência do Morro do Castelo. Com sua mudez, falar de um Rio de Janeiro colonial que a República não queria mais.

Na "Arcada das Pedras" se observava outros fragmentos que deixavam de fazer sentido em seus lugares de origem. Portas e portões que perderam suas funções de abrir e fechar, placas que deixaram de informar ou simbolizar, grades e tantas outras pedras. Objetos que, ao serem retirados do seu lugar, perderam a sua vida útil e passaram a ter apenas a vida simbólica, a vida que os visitantes do museu passaram a imaginar que tiveram um dia.

Tratava-se de um exercício de supervalorização dos objetos como possibilidade de contato com o passado. Não estava em questão a constituição de um texto temático ou cronológico, nem mesmo o auxílio da palavra nesse espaço como forma de contextualização. Mas sim a possibilidade de preencher o espaço com vestígios do pretérito, de modo que o visitante fosse envolvido pelas épocas representadas e a ele não restasse dúvidas da existência dessas épocas findas, simplesmente ao ver ou inalar o cheiro do que não mais estava no seu cotidiano. Os objetos, carregados de marcas da passagem do tempo, bastavam-se em si para essa experiência de trazer o passado ao presente através dos sentidos. 
Esta cultura antiquária revela-se como uma cultura do objeto, uma valorização por excelência dos procedimentos da autópsia, com a consequente valorização da visão em detrimento do escrito. Trata-se, na verdade, da disputa entre procedimentos que ainda têm na escrita a fonte para o conhecimento dos objetos dispostos ao olhar e aqueles que buscam uma autonomia do objeto em relação ao escrito (GUIMARÃES 2007, p. 23).

Nessa disputa, a escrita teve papel fundamental como forma de mostrar como os objetos podiam ter autonomia para falarem por si. Era através dela que se divulgava a operação (CERTEAU 1982) realizada para alcance desse objetivo, tendo os Anais da instituição como principal veículo de publicação dessa escrita. Assim mostrou artigo de autoria de Luís Marques Poliano sobre uma pedra brasonada encontrada, em 1941, nas escavações feitas para a construção de um edifício, em terreno na rua Senadora Dantas, número 20, onde em 1911 havia sido demolido parte do Convento d'Ajuda, construção de meados do século XVIII que também ocupava parte da atual Praça Floriano Peixoto, conhecida como Cinelândia. O Conservador do MHN começa seus estudos com algumas interrogações, a partir da observação das inscrições gravadas na pedra. Tratava-se de um brasão português antigo: "Que historia nos contaria ela, a que fidalgo pertencera, qual a sua época exata, que casa ornamentara e enobrecera?" (POLIANO 1947, p. 159). Após essas interrogações, Poliano nos mostra o caminho percorrido para fazer a pedra falar. Foram pesquisas heráldicas, genealógicas e arqueológicas. Leitura de documentos, relatos de 104 cronistas e historiadores sobre a cidade. Ao final de toda essa operação a pedra falou que ornamentou a fachada da casa de um fidalgo em princípio do século XVIII. Chamado Marcos da Costa Fonseca, certamente nascido na cidade do Rio de Janeiro, foi Capitão da Fortaleza de Santo Antônio da Praia da Barge. Depois que seu imóvel passou para as mãos das freiras do Convento d'Ajuda, a pedra foi retirada. Afinal, como o próprio Poliano argumentou "ela era uma marca de posse que não mais se justificava". Seu fim mais provável foi ter servido de entulho para a abertura da rua Senador Dantas (POLIANO 1947, p. 171-172).

Nesse sentido, as pedras falavam no Museu Histórico Nacional. E não apenas as pedras do Arsenal e do Morro do Castelo, mas aquelas também vindas de outras cidades, outros lugares onde o progresso as fez virarem restos de edificações derrubadas. Foi o caso da pia de água benta em mármore, da antiga Sé da Bahia recolhida em 1934, após sua demolição. Seria mais um vestígio do passado a virar escombro, mas que, ao ser coletado para integrar uma coleção museológica, recebeu outra finalidade, outro valor e tornou-se testemunha de mais uma construção colonial varrida pelas demandas da modernidade. Tornou-se testemunha também desse distanciamento cada vez maior entre o espaço de experiência e os horizontes de expectativa na forma de conceber a passagem do tempo (Cf. KOSELLECK 2006). Sua preservação junto a tantos outros vestígios de construções desaparecidas parecia contribuir para uma dupla realização do luto: pela perda irreparável do passado como experiência (GUIMARÃES 2011, p. 100) e pela perda irremediável de seus referenciais na paisagem urbana 
que se modificava rapidamente, gerando incertezas e angústias. Sensações perante a vida que talvez pudessem ser amenizadas diante de contatos com o que restava desses tempos findos, acumulados em lugares de memória criados especialmente para isso, como salientou Pierre Nora, para que a memória sobrevivesse de alguma forma, já que não estava mais presente na sua forma espontânea (NORA 1993, p. 13).

Mas, intelectuais como Gustavo Barroso, José Mariano Filho, Mário de Andrade e Alceu Amoroso Lima, entre tantos outros, reagiam à avalanche modernizadora e não se contentavam com pedras em museus. Lutavam pela preservação das pedras em seus lugares, nas edificações, nas cidades. Escreveram a respeito de cidades ditas "históricas", especialmente Ouro Preto, cidade encravada entre montanhas no interior de Minas Gerais, onde, segundo seus escritos, o progresso ainda não havia chegado para deturpar suas feições, mas onde o tempo e o abandono ameaçavam a integridade das construções que poderiam ainda dizer sobre o Brasil de outrora. Não por acaso a antiga Vila Rica, a partir da década de 1920 será o centro das atenções para assuntos preservacionistas, até se tornar a nossa Roma (BITTENCOURT 2007). Em 1933, foi a primeira cidade elevada a monumento nacional.

\section{Imagens de pedras: entre a Cidade Sagrada e a Casa do Brasil}

Ouro Preto é uma Cidade Sagrada pela história, pela arte, pela tradição e pela lenda. É um nobre patrimônio que se não pode perder (BARROSO 1944, p. 14).

Ao disparar artigos nos jornais clamando pela preservação de Ouro Preto, Barroso recorria às suas vivências na cidade como forma de sensibilizar seus leitores e, em especial, as autoridades públicas. Demonstrava assim, seu fascínio pelas pedras com sua pátina a exibir sua história: "vi o maravilhoso templo do Rosário [...] enegrecido pelo mugre dos centenários, ferido do raio, abandonado dos homens, solene e mudo sob a bênção do luar e o lume trêmulo das estrelas" (BARROSO 1944, p. 10). Fascinava-o a pedra esculpida pelos homens, mas também ferida pelos fenômenos da natureza. Suas marcas da passagem do tempo falariam do passado do lugar, mas também do passado nacional e apreensível aos sentidos: "Ouro Preto me atrai e me fascina, porque ali não é somente o passado que sinto, palpo e respiro, porém, o passado de minha terra, o passado de minha raça e o passado de minha língua" (BARROSO 1944, p. 12).

Sentir, palpar e respirar o passado era o que alimentava a imaginação. A descrição de seu passeio pela cidade mostrava o quanto a atmosfera do lugar podia nos reportar, a qualquer momento, para o século XVIII e colocar-nos em contato com personagens e fatos da história. Assim ele narrava: "e ainda sobrou tempo para rondar a Casa dos Contos, à espera de ver com os olhos da minha imaginação superexcitada os vultos dos Inconfidentes, os juízes da Alçada, a gente dos quintos do ouro e, na sua casaca de veludo azul, [...] o 
próprio Visconde de Barbacena..." (BARROSO 1944, p. 11). A preservação das construções ouropretanas parecia fundamental para alimentar essa imaginação, por isso, urgente! Por essa razão, quando as pedras de Ouro Preto foram tocadas pela Inspetoria de Monumentos Nacionais, repartição que funcionou como um departamento do Museu Histórico Nacional entre 1934 e 1937, tiveram outro destino. A equipe comandada por Barroso e pelo engenheiro Epaminondas de Macedo elegeu igrejas, pontes e chafarizes da cidade mineira para serem restaurados e, mais do que isso, revitalizados.

Procurando seguir os princípios de restauração depois sistematizados no livro Introdução às técnicas de museus, Barroso distinguia monumentos vivos dos monumentos mortos. Considerava que eram "vivos quando conservam o destino primitivo e podem sofrer certas modificações de acordo com as exigências modernas que os não afetem ou desfigurem" (BARROSO 1951, p. 90). Os mortos eram aqueles que tinham perdido seu destino original, recebendo outro. As ruínas não se enquadravam nessa distinção, por terem perdido a sua utilidade.

O que estava em jogo em Ouro Preto não eram as transformações da modernidade. Para o progresso, a República destinou uma cidade novinha em folha que assumiria a partir de 1897 as funções de centro administrativo de Minas Gerais: Belo Horizonte. Restava à antiga capital salvar-se das ruínas e do abandono de que era alvo de denúncias na imprensa. A Inspetoria estava ali para contribuir com essa tarefa. Entretanto, mais do que preservar suas edificações, buscava-se torná-la um monumento vivo. Por isso, cada pedra assumiria seu

106 lugar nas construções e, as que estivessem faltando seriam reconduzidas, 0 mais próximo possível do que já fora um dia ou do que se imaginou ter sido um dia, como demonstravam os contratos de obras da época da construção, consultados pela equipe. Bem ao estilo Violet Le Duc (2000).

Sobre as obras que foram realizadas na gestão do prefeito Melo Vianna antes da implantação da Inspetoria de Monumentos Nacionais e antes mesmo de o próprio ter sido convidado pelo governo do Estado de Minas para fiscalizar, em 1928, Barroso tecia críticas contundentes. Reclamava que as restaurações feitas na igreja de São Francisco de Assis não respeitaram a autenticidade do monumento.

As obras executadas nesse maravilhoso templo alevantado por Aleijadinho, infelizmente, não foram confiadas a um conhecedor do assunto ou a um homem de gosto e saber. Assim, meteram no corpo da igreja um rodapé de ladrilhos brancos modernos. É sabido que as igrejas de Minas, com exceção do Carmo, de Ouro Preto, não têm azulejos. A cerâmica nos tempos coloniais raramente passou do litoral para o interior devido às dificuldades de transporte, todo ele em lombo de burro ou em carros de bois. Além do grande peso, estava sujeita a quebrar-se facilmente. Apesar dos ladrilhos nesse rodapé defenderem bastante as partes inferiores das referidas paredes, seria melhor deixá-las como sempre foram. Que ao menos tivessem escolhido azulejos de estilo colonial - há tantos! -, e não esses de leiteria ou café suburbano. As portas eram verdes, como de uso nas igrejas antigas. Pintaram-nas de castanho e fingindo madeira. A mesma coisa fizeram com todas as grades e balaustradas de jacarandá. Horrível! (BARROSO 1944, p. 6-7). 
No caso dos chafarizes, por exemplo, foram utilizadas pedras retiradas do Itacolomi, chamadas itacolomito - as mesmas utilizadas para a construção de pontes no período colonial. Acreditava-se que com a reconstituição feita com materiais originais mantinha-se a autenticidade do bem restaurado. Sobre esse aspecto, Epaminondas de Macedo, responsável pelas obras, relatava a Barroso, em um de seus relatórios semanais:

Examinada a massa branca que ligava as paredes do tanque, viu-se que se compõe de cal preta magra. A análise foi feita pela Escola de Minas. Em procura da cantaria necessária aos serviços, estive na aba do Itacolomi, no local em que foi explorada a pedreira para as obras que se fizeram antigamente em Ouro Preto e ali encontrei dispersos cerca de $10 \mathrm{~m}^{2} \mathrm{de}$ lajes de itacolomito, devidamente aparelhadas. Essa cantaria será em breve transportada para a cidade. O achado nos deu material idêntico ao dos monumentos em via de restauração e preparado pelos seus próprios construtores (MACEDO 1944, p. 132, grifo nosso).

Agia-se dessa maneira como se fosse possível fazer o passado presente da maneira mais real possível. As intervenções nos monumentos realizadas pela Inspetoria tentaram fazer com que eles voltassem a ter a vida que tiveram quando foram construídos, torná-los "monumentos vivos". Para tanto, um trabalho de pesquisa nos moldes da cultura antiquária foi realizado pela equipe da Inspetoria, como demonstra Macedo em relatório enviado a Barroso em 24 de novembro de 1935, quando trata das obras no Chafariz dos Contos:

\begin{abstract}
Aberta a parede do lado esquerdo para pesquisar o paredão em esquadro a que se referem os documentos da época. Se bem que seja real ter existido, nada se poderá fazer, porque do lado presumido se acha o prédio do Banco do Comércio, construído em 1889. O chafariz foi levantado em 1765. Há vestígios da antiga casa de Manuel Rodrigues no fundo do Banco.

Descobriu-se o antigo encanamento de água, em telhas, através do paredão de frente, bem como a pia de distribuição para as bicas, que se desentupiram, levantando-se a pia, de modo que agora a água está jorrando como outrora! (MACEDO 1944, p. 132).
\end{abstract}

Foi feita a relação entre documentos escritos, preservados em arquivos oficiais e a investigação arqueológica. Alguns limites foram encontrados nesse trabalho porque a cidade é uma sobreposição de camadas temporais. Um prédio do século XIX impedia a identificação de uma construção citada na documentação escrita. Mesmo assim, foi possível realizar a obra desejada. Não estava em jogo dotar os monumentos de novos sentidos para o presente, mas devolver os usos e significados que tiveram quando foram construídos. Nessa perspectiva, os chafarizes voltaram a jorrar água, os bancos das pontes restauradas voltaram a receber pessoas para descansar e prosear entre um trajeto e outro... Barroso, desta forma, agiu como um taxidermista, que intervia nos corpos já mortos, de modo que parecessem vivos (BANN 1984). Os corpos seriam os monumentos, que dotados da vitalidade das intervenções, até conseguiam passar essa imagem de vida. Entretanto, o século XVIII que se tentava ressuscitar nessa operação, ficava a cargo da imaginação de cada habitante, de cada visitante na vivência cotidiana com o espaço urbano revitalizado. 
Neste caso, não se pretendia colecionar pedras mortas em vitrines de um museu, mas tornar a própria cidade uma coleção de pedras vivas, tornando presente um passado longínquo. Aos moradores e visitantes seria possibilitado viver como se vivia no século XVIII, ideia tão cara ao denominado turismo cultural contemporâneo que vende sonhos de uma viagem no tempo.

$\mathrm{E}$ as pedras ouropretanas - porque valoradas como históricas - não rolaram... mas também foram parar no museu em tintas e aquarelas produzidas por artistas como Alfredo Norfini, Hans Nobauer, José Washt Rodrigues, para serem vistas e admiradas em suas galerias. Obras encomendadas pelo próprio Barroso estampam monumentos e paisagens de Ouro Preto para deleite daqueles que visitavam o Museu, viabilizando uma relação entre o visível e o invisível, neste caso a cidade, distante espacialmente da capital federal. As imagens junto com outros objetos trazidos da cidade, como esculturas de Aleijadinho, banco da Casa dos Contos etc, contribuíam para inserção de Ouro Preto no projeto de construção da identidade nacional. Enfatizava-se não apenas o valor de antiguidade e artístico das edificações selecionadas para a perenidade em cores, como a "lenda negra de Santa Efigênia, onde os cajus de pedra dos púlpitos são um dos raros documentos da estilização de nossas coisas pelos nossos artistas de antanho [e] os chafarizes com seu latim e seus motivos variados dentro do mesmo estilo vigoso [sic]" (BARROSO 1944, p. 11). Mas, exaltava-se também o valor histórico (Cf. RIEGL 2013) de lugares como a Casa dos Contos e a antiga Casa de Câmara e Cadeia - atual Museu da Inconfidência - construções 108 relacionadas à história da Inconfidência mineira.

\section{Memória da viagem, viagem da memória}

De sua viagem à Europa, José Lins do Rego também deixou um livro, publicado pouco depois de Portugal, semente de impérios. Sobre Sintra, ele registrou: "Lá para cima há vestígios de pedras que os mouros deixaram. Mas o que fala dos mouros em Sintra não são as pedras antigas, são os homens trigueiros, é a cantiga carnal que cantam no fado e geme nas guitarras" (REGO 2004, p. 191). Não é a mesma coisa de Barroso. Aliás, até se percebe uma certa contraposição. Para José Lins, a carne diz mais e melhor. Por outro lado, ele acaba cedendo aos apelos das ruínas, não em Portugal, mas em outro país: "As pedras que sobraram das invasões funestas estão vivas, bem mais vivas que as casas modernas da cidade nova. [...] Não há necessidade de guias falantes para compreendermos a grandeza do Partenon" (REGO 2004, p. 227).

Pode-se até argumentar que aí a pedra é mesmo irresistível: apela tanto que se torna audível. Mas o certo mesmo é que a matéria não se torna comovente à toa. Afinal não é o passado, sozinho, que se dirige ao presente. A Grécia, no decorrer do século XIX, foi se afirmando como "lugar do passado", propício a esse exercício de compor imagens da história, dotando-as de valor especial e legítimo, como bem ressalta Manoel Luiz Salgado Guimarães, em sua análise sobre uma carta que Freud escreveu ao poeta Romain Rolland em 1936. A carta chegou ao destinatário com um texto intitulado "Uma perturbação da lembrança sobre a Acrópolis", relatando a visita à Atenas em 1904. Mais especificamente, 
o relato a respeito das expectativas que antecederam a viagem e, depois, o impacto marcante de contemplar o cenário, que o fez concluir: "Então existia mesmo tudo aquilo, da maneira como aprendêramos na escola". Nesse vislumbre, tido no calor da hora e registrado três décadas depois, Manoel Luiz Salgado percebe uma via de acesso para se pensar a relação entre escrita da história e a sistematização de certos usos do passado que passara a vigorar, de modo mais decisivo, a partir do século XIX, inclusive na própria constituição da psicanálise:

a interpretação freudiana para sua própria experiência, misturando deslumbramentos e incredulidade, aponta para sua história familiar, na qual busca os nexos explicativos para os sentimentos despertados pela visão daquilo a que só tivera acesso através dos livros: a Atenas que povoara a imaginação e a formação de inúmeras gerações de estudantes dos ginásios de língua e cultura alemã no século XIX (GUIMARÃES 2010, p. 34).

Um passado que, por ser finito, estava finado. Mas, contraditoriamente, continuava presente: "a mesma Grécia e Atenas, que no século anterior haviam sido o objeto privilegiado das reflexões de Winckelmann, que as torna assim significativas para a cultura alemã". A visão diante da pedra desgastada dava ao próprio passado uma legitimidade concreta, mais tangível do que o próprio texto de história:

a visão, conforme a experiência vivenciada por Freud do alto da Acrópolis, parecia assegurar a realidade efetiva da própria História na forma em que era ensinada e que ele aprendera. Visão e escrita pareciam completar-se na tarefa de tornar o passado uma evidência, uma certeza e, por isso, objeto passível de um conhecimento (GUIMARÃES 2010, p. 34).

A pedra, nisso tudo, ocupa lugar de destaque: seu testemunho pode ser mais antigo devido à sua própria durabilidade. Além disso, ou subjacente a isso, há outro fator: a ruína chega à visão carregando uma certa ambiguidade a respeito da sua própria condição de matéria-prima, talhada pela mão e pelo tempo. Natureza e cultura: matéria bruta e burilada. Burilada não só pelo labor da humanidade ancestral, mas também pela mão da natureza, tão inumana quanto a própria matéria da pedra: a sequência incessante de intempéries, em seu destino imponderável que vai marcando aos poucos, tanto na corrosão, quanto na tintura que se acumula em sulcos e detalhes. Daí a ênfase que Victor Hugo dá ao "enegrecido" das letras esculpidas, cujo desaparecimento lhe fez indignado e inspirado (palavras que, para ele, não poderiam ser desatadas):

Assim, além da frágil lembrança que Ihe consagra o autor deste livro, hoje já nada mais existe da palavra misteriosa gravada na sóbria torre de Nossa Senhora de Paris, nada do fim desconhecido que ela tão melancolicamente resumia. $O$ homem que escreveu aquela palavra naquela parede desapareceu, há muitos séculos, do meio das gerações, a palavra, por sua vez, já desapareceu da igreja, e a própria igreja talvez que bem cedo desapareça também da terra. Foi sobre essa palavra, que este livro foi escrito. Fevereiro de 1831 (HUGO 2011, p. 5). 
A luta de Victor Hugo para deter o "martelo que mutila" passou a ser amplamente reconhecida, sobretudo no final do século $X X$, em sua ânsia pela "preservação da memória". Afinal, a sensibilidade contemporânea tornou-se reverente ao pioneirismo do romancista em 1825, em seu apelo para que houvesse uma lei ("apenas uma", ele ressalta) para impedir a destruição de edifícios históricos, com o devido estabelecimento de restrições ao direito de propriedade (CHOAY 2001, p. 149). Não é propriamente isso que aqui se põe em destaque, e sim algo que se relaciona a um uso mais impreciso do passado: a pedra como testemunha do transcorrer dos séculos. O que Victor Hugo escreve sobre seu achado no pé da torre diz respeito a um passado sobre o qual nada se sabe, mas está ali.

Mas não se tratava de lidar com o fato já revelado ou ainda oculto, como seria normal no pensamento de um historiador de então. O mistério incrustrado na pedra seria o tônus da pena que percorre o papel, dando ao leitor a impressão nítida de um passado real, retirado da matéria, não como se retira o cadáver de um túmulo, mas como oração ao morto. Lápide ambulante, capaz de figurar na reprodução do milagre tipográfico, que os livreiros colocavam em circulação.

Em termos usados por Michel de Certeau (1982) para caracterizar a escrita da história, os protocolos regiam-se por uma ausência radical, aquela que só a morte traria. Diante do vazio fragmentado, cortante, pontiagudo: a escrita que junta pedaços, costura e cicatriza. O passado por escrito seria, então, essa lápide que identifica e faz a homenagem necessária e apaziguadora, para que 110 haja mais espaço para os que já e ainda estão vivos. É claro que a influência da psicanálise nessa conclusão de Certeau é nítida. Mas, vale ressaltar, a elaboração também se inspirou no romantismo de Michelet, em sua recorrente referência ao trabalho do historiador como dever piedoso diante dos sepultados. Victor Hugo e Alencar estão, nesse sentido, no mesmo barco, porém acreditam que o fato deve ser tratado de uma maneira específica, ou melhor, em outra medida. Qualquer descuido pode estragar a lápide: o romance se transforma em relato, a forma se corrompe na fórmula, a excitação cai na explicação, e o sentimento vira apenas sentido.

Uma antiga inscrição misteriosa destruída para sempre. Diante disso, lamento, revolta, reverência, denúncia, homenagem. Tudo isso se envolve, então, numa espécie de narrativa da perda duplicada: o próprio romance. Daí tentativa de compor na ficção uma realidade perene, substrato que a pedra não conseguiu dar à inscrição (que significa FATALIDADE, conforme o leitor fica sabendo mais ou menos na metade do livro, já que a palavra em grego não aparece somente na nota introdutória, entrando também na trama da narrativa). A inscrição marcava a existência de algo, cuja mensagem tornava-se praticamente indecifrável, mas o indício estava ali, como prova concreta do que não mais existia. O escritor, nesse e em outros escritos, lutava pela preservação de traços dos ausentes. Somente desse modo, os ausentes ganhariam lugar no presente e no futuro, continuariam a mostrar que o tempo era denso: presente, passado e futuro, em camadas interativas. Com o desaparecimento do rastro, desapareceria a perda, deixando a vida na superficie. Assim pensando, o escritor 
partilhava uma experiência que pode ser tomada como basilar na própria constituição da história no século XIX.

É por isso que Manoel Luiz Salgado relaciona a formação da escrita da história com o texto de Freud sobre a diferença entre o "trabalho de luto" e a "melancolia". O que vai Ihe interessar não é a "melancolia", que, em certa medida e em certo sentido, pode ser associada à sensibilidade dos românticos. $\mathrm{Na}$ análise que Manoel Luiz faz da perspectiva freudiana, o que vai chamar mais atenção é o "trabalho de luto": "... a experiência da perda de sentido do mundo, que demanda um trabalho de reconfiguração de sentidos para a vida neste mundo abalado pela dor da perda. Movimento, portanto para a vida, para o mundo e para os outros, ainda que a partir de uma experiência da dor e da consciência da finitude" (GUIMARÃES 2010, p. 48).

O luto, portanto, é um esforço direcionado, necessariamente envolvido no "trabalho consciente". Se o texto analisado é de 1917, não escapa a Manoel Luiz um comentário preciso e decisivo sobre o atrelamento da escrita de Freud com a perplexidade vivida pelo mundo de então: "Momento especialmente tenso da história da humanidade, a vivência de uma primeira conflagração de ordem mundial, parece ser o pano de fundo importante para compreendermos as reflexões de Freud a este respeito e suas implicações, portanto, com a própria História". Numa interpretação que lembra Michel de Certeau, Manoel compôs uma tessitura que, para findar, recomeça, dando ao leitor a medida justa e imponderável da multiplicidade do tempo:

Voltemos ao lugar de onde partimos: a lembrança que parece recorrente a

Freud de sua experiência sobre a Acrópolis, uma experiência que envolve uma relação com o passado, não apenas sua, mas a de uma cultura que se funda na tradição histórica oitocentista por ele partilhada. Essa lembrança parece ganhar força num momento em que para o próprio Freud a consciência do limite e da aproximação de uma perda definitiva - para um homem de oitenta anos - se fazem mais presentes. E esta consciência, transformada em elaboração textual, é o presente escolhido para homenagear o amigo por mais um ano de vida: uma afirmação da vida e do outro a partir de sentidos reconfigurados. É esta mesma consciência da perda, que torna tão necessárias estas imagens e figuras do passado diante dos nossos olhos, ajudando-nos a reconfigurar o mundo da existência presente, produzindo a vida pela história. Os inúmeros projetos da cultura histórica oitocentista, como por exemplo, o dos museus históricos nacionais, aponta neste sentido, para que também possamos, como Freud do alto da Acrópolis de Atenas, exclamar: "Então existia mesmo tudo aquilo, da maneira como aprendêramos na escola" (GUIMARÃES 2010, p. 48).

Está aí, portanto, uma lição que a pedra pode dar: "então, existiu". A mesma pedagogia da história em seu "trabalho de luto"? Em certo sentido, sim, na medida em que estão em jogo maneiras de tornar o tempo compressível e minimamente aceitável. Contudo, se o foco é especificamente as pedras aqui expostas, a partir de diferentes dispositivos de escritas sobre o passado, seja a escrita literária, a musológica ou a de preservação do patrimônio arquitetônico, o que parece prevalecer, a depender da circunstância, é a "melancolia". Há, 
enfim, uma espécie de tempo da natureza, responsável pela carga de tempo que um artefato passa a ter. Sol, chuva, neve, vento, tudo isso conta, além da própria marcação das intervenções humanas. São essas camadas de tempo que fascinam escritores como Alencar, Barroso, José Lins ou Victor Hugo.

\section{Referências bibliográficas}

ALENCAR, José de. O Rio de Janeiro - prólogo. In: FREIXEIRO, Fábio. Alencar: os bastidores e a posteridade. Rio de Janeiro: Museu Histórico Nacional, 1981, p. 110-113.

Alfarrábios: Crônicas dos Tempos Coloniais, I - O garatuja, II - O ermitão da glória, III - a alma do Lázaro. Rio de Janeiro: Livraria José Olímpio Editora, 1953.

BANN, Stephen. The Clothing of Clio: A study of the representation of history in nineteen-century Britain and France. Cambridge: Cambridge University Press, 1984.

BARROSO, Gustavo. Seca e Meca e olivais de Santarém. São Paulo: Presença, 1946.

. A cidade sagrada... Anais do MHN, v. 5, p. 10-14, 1944 [1928].

. O culto da saudade. Anais do MHN, v. 29, p. 32-34, 1997 [1912].

. Introdução à técnica de museus. Rio de Janeiro: Gráfica Olímpica, v. $1,1951$.

. Introdução à técnica de museus. Rio de Janeiro: Gráfica Olímpica, v. 2, 1953.

. Portugal, semente de impérios. Rio de Janeiro: Getúlio Costa, 1943.

BITTENCOURT, José Neves. Ouro Preto, nossa Roma: Antiquários e tradições numa trajetória de preservação. Oficina do Inconfidência, Ouro Preto, v. 4, p. 123-137, 2007.

CARENA, Carlo. Ruína/Restauro. In: ROMANO, Ruggiero (dir.). Enciclopédia Einaudi. Lisboa: Imprensa Nacional, 1984, p. 107-129.

CERTEAU, Michel de. A escrita da história. Rio de Janeiro: Forense Universitária, 1982.

DOSSE, François. História e historiadores no século XIX. In: MALERBA, Jurandir (org.). Lições de história: o caminho da ciência no longo século XIX. Rio de Janeiro: FGV, 2010, p.15-32.

GUIMARÃES, Manoel Luiz Salgado. História e natureza em von Martius: esquadrinhando o Brasil para construir a nação. História, ciência e saúde. v. 7, n. 2, p. 391-413, jul./out 2000.

A disputa pelo passado na cultura histórica oitocentista no Brasil. In: CARVALHO, José Murilo de. Nação e Cidadania no Império: novos horizontes. Rio de Janeiro: Civilização Brasileira, 2007, p. 93-122. 
. Expondo a história: imagens construindo o passado. In: GUIMARÃES, Manoel L. S.; RAMOS, Francisco Régis L. (orgs.). Futuro do pretérito: escrita da história e história do museu. Fortaleza: Edições NUDOC/UFC, 2010, p. 34-49.

.História, memória e patrimônio. Revista do IPHAN, n. 34, p. 91-111, 2011.

. Reinventando a Tradição: sobre antiquariado e escrita da história. In: RIOS, Kênia Sousa; FURTADO FILHO, João Ernani (org.). Em tempo: história, memória, educação. Fortaleza: Imprensa Universitária UFC, 2008, p. 39-80.

HUGO, Victor. Notre-Dame de Paris. São Paulo: Estação Liberdade, 2011.

KOSELLECK, Reinhart. Futuro passado: contribuição à semântica dos tempos históricos. Rio de Janeiro: Contraponto; Ed. PUC/RIO, 2006.

MACEDO, Epaminondas. Relatório em 24 de novembro de 1935. ANAIS DO MHN, v. 5, 1944, p. 130-133.

MOMIGLIANO, Arnaldo. O surgimento da pesquisa antiquária. In: As raízes clássicas da historiografia moderna. Bauru: EDUSC, 2004, p. 85-117.

MHN. Catálogo Geral do Museu Histórico Nacional: primeira seção arqueologia e história. Rio de Janeiro: Imprensa Nacional, 1924.

NORA, Pierre. Entre história e memória: a problemática dos lugares. Projeto história, v. 10, p. 37-44, 1993.

PELOGGIO, Marcelo. José de Alencar: um historiador à sua maneira. Revista Alea, v. 06, n.01, 82-94. janeiro-junho, 2004.

POLIANO, Luís Marques. Uma pedra brasonada do Rio Antigo. Anais do MHN, v. 4 , p. $157-179,1947$.

POULOT, Dominique. Uma história do patrimônio no Ocidente, séculos XVIIIXIX: do monumento aos valores. São Paulo: Estação Liberdade, 2009.

RIEGL, Aloïs. $O$ culto moderno dos monumentos. Coimbra: Edições 70, 2013.

REGO, José Lins. O cravo de Mozart é eterno. Crônicas e Ensaios. Seleção, organização e apresentação de Lêdo Ivo. Rio de Janeiro: José Olympio, 2004.

VIOLLET-LE-DUC, Eugène E. Restauração. Cotia: Ateliê Editorial, 2000. 